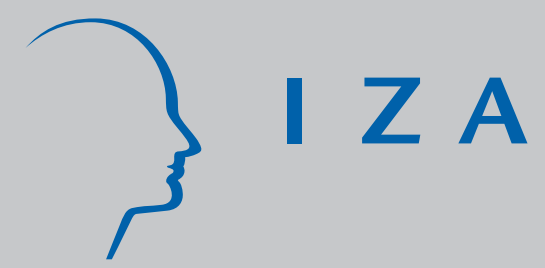

IZA DP No. 4677

Intergenerational Mobility of Immigrants in Germany: Moving with Natives or Stuck in their Neighborhoods?

Mutlu Yuksel

December 2009 


\title{
Intergenerational Mobility of Immigrants in Germany: Moving with Natives or Stuck in their Neighborhoods?
}

\author{
Mutlu Yuksel \\ IZA
}

Discussion Paper No. 4677

December 2009

\author{
IZA \\ P.O. Box 7240 \\ 53072 Bonn \\ Germany \\ Phone: +49-228-3894-0 \\ Fax: +49-228-3894-180 \\ E-mail: iza@iza.org
}

Any opinions expressed here are those of the author(s) and not those of IZA. Research published in this series may include views on policy, but the institute itself takes no institutional policy positions.

The Institute for the Study of Labor (IZA) in Bonn is a local and virtual international research center and a place of communication between science, politics and business. IZA is an independent nonprofit organization supported by Deutsche Post Foundation. The center is associated with the University of Bonn and offers a stimulating research environment through its international network, workshops and conferences, data service, project support, research visits and doctoral program. IZA engages in (i) original and internationally competitive research in all fields of labor economics, (ii) development of policy concepts, and (iii) dissemination of research results and concepts to the interested public.

IZA Discussion Papers often represent preliminary work and are circulated to encourage discussion. Citation of such a paper should account for its provisional character. A revised version may be available directly from the author. 
IZA Discussion Paper No. 4677

December 2009

\section{ABSTRACT \\ Intergenerational Mobility of Immigrants in Germany: Moving with Natives or Stuck in their Neighborhoods?*}

In this paper, I analyze intergenerational mobility of immigrants and natives in Germany. Using the German Socioeconomic Panel (GSOEP), I find intergenerational elasticities that range from 0.19 to 0.26 for natives and from 0.37 to 0.40 for immigrants. These elasticity estimates are lower than typically found for the U.S. and imply higher mobility in Germany than in the U.S. However, as in the U.S., I find greater mobility among German natives than among immigrants. Moreover, I investigate to what extent the lower mobility among immigrants in Germany is due to "ethnic capital" as suggested by Borjas (1992). I find that the impact of father's earnings on son's earnings remains virtually unchanged when including a measure of ethnic capital, suggesting that the higher father-son correlation found among immigrants is not due to omitting ethnic capital. However, I do find a large independent effect of ethnic capital on sons' earnings (the coefficient is 0.81 as opposed to 0.25 found by Borjas (1992)). These results are consistent with estimates from Microcensus data, where the combined effect of parents' and ethnic capital is close to unity. Thus, contrary to the U.S. results which suggest convergence of immigrants' earnings towards natives' earnings, the German results suggest divergence of immigrant earnings.

JEL Classification: J61, J62

Keywords: immigration, intergenerational mobility, natives, ethnic capital

Corresponding author:

Mutlu Yuksel

IZA

P.O. Box 7240

D-53072 Bonn

Germany

E-mail: yuksel@iza.org

\footnotetext{
*I am especially grateful to my advisors, Chinhui Juhn and Adriana Kugler for very useful comments. I also thank Aimee Chin, as well as seminar participants at DIW Berlin, Germany, for their comments. I also thank the DIW for financial support and its staff for help with the data.
} 


\section{Introduction}

From the late 1970 s to the early 1990 s, immigrant inflows increased dramatically in OECD countries (OECD (1999a)). Immigration into Germany began during the 1960s and the 1970s when Germany invited approximately 3 million "guest workers" from southern Europe (Spain, Italy, and Greece), the former Yugoslavia and from Turkey. More recently, 2.5 million people from Eastern Europe moved to unified Germany since reunification occurred 15 years ago. As a result of these earlier and more recent inflows, children of immigrants now constitute 10 percent of the young population in Germany. An important question is whether this second generation has been able to integrate rapidly into the native population or whether they have inherited the disadvantages faced by the first generation of immigrants.

Immigrant assimilation has been much less studied in Europe than in the U.S. partly because immigration has a much shorter (modern) history in Europe. Important institutional differences in the labor market, in the tax system, in the education system as well as the role of the family in the transmission of human capital between generations, suggest that there might be important differences in the possibilities of reaching longterm assimilation between the U.S. and Europe. The main objective of this paper is to analyze intergenerational mobility of immigrants and natives in Germany. A large literature has developed in the late 1980s and the first half of 1990 s concerning the correlation of economic status across generations in the United States. However, there has been much less research about the intergenerational mobility in Germany, and no papers have investigated the importance of ethnic capital in Germany. Borjas (1992) lays 
out a framework in which "ethnic capital," the average human capital level of the ethnic group in the father's generation, has an external effect on the human capital investment in the son's generation. In this paper I examine the importance of ethnic capital in Germany using two alternative methods. First, I examine the impact of father's income and the average income of father's ethnic group and cohort on son's income using the data from the German Socio-economic Panel (GSOEP). I supplement this analysis with Microcensus using the between-group methods used by Borjas (1993) and Card, DiNardo, and Estes (2000). To preview my main results, I find that the intergenerational elasticity of son's income with respect to father's income ranges from 0.19 to 0.26 for natives and from 0.37 to 0.40 for immigrants. On their own, these results would suggest greater mobility in Germany than in the U.S. However, I also find a large effect of ethnic capital, which contributes to generate a lot of persistence in earnings among immigrants in Germany. When the ethnic capital variable is included in the father-son regression, the coefficient on father's income remains virtually unchanged while the coefficient on the ethnic capital is significant and large, ranging from 0.62 to 0.82 . These results are consistent with estimates from Microcensus data, where the combined effect of parents' and ethnic capital is close to unity. Consequently, including ethnic capital is very important. Contrary to the results which only include father's income, the results that include ethnic capital suggest much less mobility for immigrants in Germany than for immigrants in the U.S.

The remainder of the paper is organized as follows. Section 2 briefly reviews previous papers. Section 3 describes the main empirical strategy. Section 4 describes the data. Section 5 presents the main results on the elasticity of son's income with respect to 
father's income for natives and immigrants as well as the results on ethnic capital. Section 6 investigates possible channels of the intergenerational transmission of status by examining education, occupation, as well as before and after-tax family income. Section 7 concludes.

\section{Literature Review}

The concept of the intergenerational mobility has been on the agenda of researchers since the publication of well-known pioneering study by Becker and Tomes $(1979,1986)$, which introduced the theory of the intergenerational mobility for the first time. Following this paper, an extensive literature emerged trying to quantify the extent of intergenerational mobility. Most of the earlier studies used cross sectional data for a single year. Thus, these suffer from measurement error in income and it is also the case that income from a single year may be largely driven by transitory shocks. For this reason, later studies have relied on panel data and have relied on instrumental variables to get at the impact of the father's permanent income on children's income. These later studies show much lower mobility than the earlier studies suggested. Solon $(1989,1992)$, Zimmerman (1992), Björklund and Jäntti (1997), Couch and Dunn (1997), Mulligan (2001), Grawe (2004) examine the income elasticity between generations and find that the intergenerational elasticity and correlation in long-run income is around 0.4 for USborn males. These results suggest that a grandchild is $16 \%$ as likely to have the same income as their grandfather, while the earlier studies suggested that a grandchild was only $4 \%$ as likely to have the same income as his grandfather. 
While a handful of studies examine the degree of intergenerational mobility for the US-born males, few studies have attempted to investigate the intergenerational transmission of immigrants. $\operatorname{Borjas}(1992,1994)$ states that the process of intergenerational mobility of immigrants may differ from that of the natives. It is likely that the immigrant children are exposed to the culture, attitudes, language of their ethnic groups and, therefore the ethnic environment of the parent generation might be crucial in explaining the degree of intergenerational mobility. Borjas defines this concept as "ethnic capital". More recently, a study by Card, DiNardo and Estes (2000) uses US census data to study the mobility of immigrants across various over generations and finds that the intergenerational mobility is greater for immigrants than that for natives among both the younger and older cohorts.

While an extensive literature has developed on the extent of the intergenerational mobility for the US, relatively little is known regarding the intergenerational transmission for natives and immigrants in other major industrialized countries. A handful of studies have addressed the degree of intergenerational mobility in Scandinavian countries, including Osteberg (2000) for Sweden, Bratberg at al. (2003) for Norway, Österbacka (2003) for Finland. Overall, these studies suggest that the Scandinavian countries are more mobile than the U.S. Likewise, the study by Daerden et al. about UK and other two studies by Corak (2004) and Grawe (2004) about Canada suggest more mobility in terms of socioeconomic status in the U.K. and Canada than in the U.S.

In spite of extensive immigration in the 1960's and 1970s and the more recent immigration in the 1990s into Germany, few studies have attempted to investigate the process by which the intergenerational mobility takes place in this country. The study by 
Couch and Dunn (1997) is the first to examine the correlation between the labor market outcomes of a child and his or her parent for German natives. This study offers a direct comparison between US and Germany using the same estimation technique on similar samples drawn from panel data sets covering the same multiyear time period. Contrary to studies for other industrialized countries which suggest more mobility in these countries than in the U.S., the empirical analysis suggests that children in Germany are as likely as their U.S. counterparts to inherit the economic and social status of their parent. Similarly, two other studies by Lillard (2001) and Grawe (2004) find using GSOEP that the intergenerational mobility in Germany is around 0.10 . However, these studies are subject to a number of problems. First, the studies fail to consider parents and children at similar stages in their life-cycles, which would bias results towards greater mobility as children of poor parents will be already employed and children of wealthy parents will likely still be doing internships and taking their first jobs after completing University degrees. Second, because these studies do not consider natives and immigrants separately, they ignore the potential role of ethnic capital and are likely to overestimate the extent of mobility.

\section{Estimation Strategy}

\section{3.a.. Effect of Parental Capital}

In this section, I lay out the basic framework used by Solon (1992) and Zimmerman (1992) to estimate the effect of father's long run income on son's long-run income. Let $\mathrm{Y}_{1 \mathrm{i}}$ will be the long-run economic status (income) for a son in family $\mathrm{i}$, and 
let $\mathrm{Y}_{0 \mathrm{i}}$ be the same variable for his father. Then, intergenerational income mobility can be estimated by applying least squares to the regression equation

$$
\mathrm{Y}_{1 \mathrm{i}}=\alpha+\beta \mathrm{Y}_{0 \mathrm{i}}+\varepsilon_{1 \mathrm{i}}
$$

where $\alpha$ is the average adult income of the son's generation, $\mathrm{Y}_{0 \mathrm{i}}$ is average income of the father's generation, $\varepsilon_{1 \mathrm{i}}$ is an error term assumed to be white noise.

The average income of a generation may evolve through time. For example, it may be that many or all members of a generation will have incomes higher than what their parents had at a similar age in the past. Just as importantly, equation (1) reflects the idea that individual's income is nonetheless related to his or her parents' income. The coefficient $\beta$ measures the degree of persistence or immobility in the society and is the fraction of the father's relative position that his son inherits. If income is in logarithms, then $\beta$ is the elasticity of son's long run income to father's long run income. Estimates of $\beta$ close to unity point to high persistence and limited mobility whereas values of $\beta$ close to zero indicate low persistence and close to complete intergenerational mobility. Presumably, any real number could be obtained from the estimation of equation (1); a negative value of $\beta$ would refer to a situation where parents are high in their distribution of income, while their children tend to be low in their own generations' income distribution. Although most empirical studies investigate the intergenerational mobility between fathers and sons and find $\beta$. to lie between zero and one, some studies that explore the mobility between father-daughter and mother-daughter pairs have found negative estimates of $\beta$. 
Previous estimates of intergenerational mobility obtained by applying least squares to equation (1) have been criticized for several reasons. ${ }^{2}$ First, they did not use long-run income but instead used single-year measures of earnings or income. Second, many previous studies used homogenous and unrepresentative samples. These problems generated downward biases in the estimated intergenerational elasticity. Solon (1992) and Zimmerman (1992) offer various solutions which I adopt in this paper. Equation (1) specifies a relationship between long-run or permanent incomes of fathers and sons which are not observed. The current income, $\mathrm{Y}_{\mathrm{it}}$, of the father or son can be modeled as consisting of three components as in the following

$$
\mathrm{Y}_{\mathrm{it}}=\mathrm{Y}_{\mathrm{i}}+\gamma \mathrm{X}_{\mathrm{it}}+\mathrm{v}_{\mathrm{it}}
$$

where $Y_{i}$ measures permanent income, $X_{i t}$ is a set of factors which cause current income to deviate from permanent income such as age and year indicators, and $v_{\text {it }}$ is a transitory error component. ${ }^{3}$ Estimation of equation (1) with "adjusted status" yields a biased estimate of intergenerational mobility parameter $\beta$. If least squares estimation is applied, then $\beta$ will be downwardly biased. In particular, if all error components of both generations' transitory status, permanent status, and age are uncorrelated with and within each other, then the probability limit of the estimated slope coefficient, shown in (3), is the bias arising from the classical errors in variable problem:

$$
\operatorname{Plim} \beta \text { hat }=\beta\left[\sigma_{\mathrm{y}}^{2} /\left(\sigma_{\mathrm{y}}{ }^{2}+\sigma_{\mathrm{v} 0}{ }^{2}\right)\right]<\beta
$$

The magnitude of this bias depends on the ratio of signal to total variance,

\footnotetext{
${ }^{2}$ Hauser, Sewell, and Lutterman (1975); Atkinson(1981); Behrman and Taubman(1983)

${ }^{3}$ Following Zimmerman (1992), I estimate equation (1) in two steps. I first regress log income on age, age squared, and year dummies for fathers and sons separately and construct residuals which I refer to as "adjusted current status" and use the residuals to estimate equation (1).
} 
$\sigma_{\mathrm{y}}{ }^{2} /\left(\sigma_{\mathrm{y}}{ }^{2}+\sigma_{\mathrm{v} 0}{ }^{2}\right)$, where $\sigma_{\mathrm{y}}{ }^{2}$ is the variance of father's long-run status, and $\sigma_{\mathrm{v} 0}{ }^{2}$ is the variance of father's transitory status. Like most recent studies, I decrease this bias by taking averages of income over multiples years. Applying least square estimation and assuming the errors are uncorrelated over time would yield an estimate of $\beta$ with probability limit

$$
P \lim \beta_{\text {avg }}=\beta\left[\sigma_{y}^{2} /\left(\sigma_{y}^{2}+\left(\sigma^{2}{ }_{v 0} / T\right)\right)\right]
$$

where $\mathrm{T}$ is the number of years. As $\mathrm{T}$ increases, the bias decreases.

However, as Zimmerman (1992) shows, the assumption that the transitory components of current income are uncorrelated over time may be too strong an assumption and can be relaxed by using cross-sectional variation in earnings. If the transitory component of fathers' earnings followed AR (1), i.e. $\mathrm{v}_{0 \mathrm{it}}=\rho \mathrm{v}_{0 \mathrm{it}-1}+\xi_{\mathrm{it}}$, then plim of $\beta_{\text {avg }}$ can be found by replacing $\sigma_{\mathrm{v} 0}^{2}$ with $\left(\sigma_{\mathrm{v} 0}^{2} / \mathrm{T}\left(1-\rho^{2}\right)\right)\left\{1+2 \rho\left[\mathrm{T}-\left(1-\rho^{\mathrm{t}}\right) /(1-\rho)\right] / \mathrm{T}(1-\right.$ $\rho)\}$ in equation (3). Following this method, I assume that both fathers' and sons' transitory error components follow AR (1) process. Also, I average multiple years of income to address serial correlation in the $\mathrm{v}_{\mathrm{it}}$ ' $\mathrm{s}$.

Estimates of permanent earnings will suffer from measurement error if the sample contains individuals who have reported earnings only for a small number of years. To eliminate this problem, Solon (1992) and Zimmerman (1992) include only individuals who were fully employed in all years. In this paper, I compare the results from using individuals who have income at least one year to those using multiple years.

Haider and Solon (2005) show that any regression model that uses annual earnings as a proxy for life-time earnings may give biased estimates if there is earnings growth rate heterogeneity. Their empirical analysis shows that the standard assumption of 
the classical errors-in-variables is well founded if sons' earnings are measured between their early thirties and mid-forties. Previous studies of intergenerational mobility in Germany are likely to suffer from this problem since the average age sons used are in the twenties. Since the sons in my sample are on average in their mid-thirties, this is less likely to be a concern in this study.

\section{3.b. Effect of Ethnic Capital}

The intergenerational transmissions among immigrants may work through at least two different channels: the direct effect from parents ("parental capital"), the effect of the ethnic group ("ethnic capital" or "neighborhood effect"). Borjas $(1992,1993)$ points out that the estimate of the intergenerational elasticity, $\beta$, may be biased upwards for immigrants if the average socio-economic status measure of the father's ethnic group and cohort is correlated with the father's own socio-economic status and if the average value of the father's ethnic group plays a role in determining the long-run status of children. Adding the ethnic variable effect to equation (1), we now have:

$$
\mathrm{Y}_{1, \mathrm{i}, \mathrm{j}}=\alpha+\beta_{1} \mathrm{Y}_{0, \mathrm{i}, \mathrm{j}}+\beta_{2} \mathrm{Y}_{0, \mathrm{j}}+\varepsilon_{\mathrm{i}}
$$

where $Y_{1, i, j}$ represents income of the son from family $i$, nationality $j$, and $Y_{0, i, j}$ represents the income of the father from family $i$, nationality $j$, and $Y_{0, j}$ represents the average incomes of fathers from the same country of origin. The coefficient $\beta_{2}$ capture the impact of the ethnic spillover. With ethnic capital, the degree of persistence can be measured by the sum of coefficients $\beta_{1+} \beta_{2}$. The degree of persistence may be substantially underestimated by taking account of only parental capital and by ignoring ethnic capital. The combined effect, $\beta_{1+} \beta_{2}$, can also be estimated using Census data following the 
methods used by Borjas (1992, 1993, and 1994). While father-son pairs cannot be identified in census data, under the appropriate assumptions, we can estimate the persistence rate as the combined effect as in the following

$$
Y_{1, j}=\alpha+\left(\beta_{1+} \beta_{2}\right) Y_{0, j}+\varepsilon_{i}
$$

$\mathrm{Y}_{1, \mathrm{j}}$ represents the average earnings of sons from the same nationality, and $\mathrm{Y}_{0, \mathrm{j}}$ represents the average earnings of fathers from the same country of origin. The transmission parameter describing how the mean skills of the ethnic group evolve across generations is given by the sum of coefficients, $\beta_{1+} \beta_{2}$.

\section{Data and Descriptive Statistics}

In this paper I rely on two sources of data to analyze native and immigrant mobility in Germany. First, I use the German Socio-Economic Panel, which has data on both native and immigrant parents and their children and which allows to separately analyze the impact of parents' socio-economic status and the impact of ethnic socioeconomic status on children. Then, I turn to German Census to examine the joint effect of parents' and ethnic socio-economic status on immigrants using data from a larger dataset. In turn, I describe each of these datasets.

\section{4.a. German Socio-economic Panel (GSOEP)}

The bulk of my empirical analysis uses nationally representative data from the German Socio-economic Panel (GSOEP) ${ }^{4}$. The most important feature of this

\footnotetext{
${ }^{4}$ Information on data sources and extracts is provided in the data appendix.
} 
dataset in my context is that it over-samples foreigners and also provides information on their pre-immigration profiles as well as their own education and their parents'.

For this study, I only use the data for fathers from the former West Germany and their sons. The main reason for this choice of sample is that there are large differences in socio-economic differences between the former West Germany and East Germany in terms of economic environment, career opportunities, the education system as well as basic vocational training opportunities. Besides, the vast majority of the guest workers were invited by the government of former West Germany. Since then, these guest workers have been working in different sectors in the former West Germany. In addition, their children attended schools in the former West Germany and also work in West Germany. For this reason, it seems reasonable to compare the intergenerational mobility of natives and these guest workers who live in West Germany.

As a final point, family, individual and relationship identifiers in the GSOEP allow us to match sons and fathers. I construct a sample of father-son pairs for both immigrants and natives. I define first generation immigrants (fathers) as those who immigrated to Germany regardless of the age of arrival. Additionally, I identify second generation immigrants (sons) to be individuals who were either born in Germany or who migrated to Germany before 6 years of age and who are not German nationals.

My analysis is primarily conducted using 647 father-son pairs for natives and 269 for immigrants. I include all fathers who had full-time employment in any year between 1984 and 1989 and all sons whose father was in the GSOEP and who had fulltime employment in any year between 2000 and 2004. I exclude observations during any 
year in which the son was enrolled in school or the parent to whom he or she is matched was enrolled in school or retired.

Table 1 provides the descriptive statistics for father-son pairs which are computed for natives and immigrants separately. The average father's age is 44.6 for natives and 45.8 for immigrants in 1984, and the average son's age is 30.8 for natives and 30.9 for immigrants in 2004. Our education measure is the highest number of completed years of schooling reported in the interval from 1984 to 1989 for fathers and from 2000 to 2004 for sons. The average education of native fathers is 11.4 and it is almost 2.5 years higher than the immigrant fathers'. On the other hand, native sons' highest-grade increases by only 1 year relative to their fathers', while for immigrant sons years of education increased by 1.8 years on average relative to their fathers'. A comparison of mean education of native and immigrant fathers and sons, thus suggests convergence of immigrants in terms of their educational attainment.

From Table 1, $(\log )$ annual labor earning of immigrant fathers is less than that of natives for all years although average earning of immigrant sons is similar to the earnings of native sons. The annual labor earnings examined in Table 1 include wages and salary from all employment plus income from bonuses. All nominal values of annual labor income are deflated using the German consumer price index. While previous studies for Germany study intergenerational mobility using current monthly income instead of annual earnings, current monthly income is a noisier measure of permanent income. Moreover, using annual earnings, as described detailed in Appendix, seems particularly important for white collar workers, who are most likely to earn additional bonuses. Table 1 show that the earnings of native sons are $14 \%$ lower than those of their fathers', while 
the earnings of immigrant sons are only $1 \%$ lower than their fathers'. While sons and parents are at different stages of their life-cycles and it is important to make age adjustments that account for this, comparisons of mean earnings of fathers and sons suggest that immigrant sons are catching up more quickly with the earnings parents than native sons.

Table 2 shows the distribution of fathers by number of sons. Since, some fathers have more than one son in the labor force; we have 518 native fathers corresponding to 647 native sons and 207 immigrant fathers corresponding to 269 immigrant sons. Table 2 indicates that $79 \%$ of the native fathers have one son, $18 \%$ of them have 2 sons and only $3 \%$ of them have more than two sons. Similarly, $78 \%$ of the immigrant fathers have only one son, $18 \%$ of them have 2 sons and almost $4 \%$ of them have more than two sons.

I implement the empirical strategy using the total number of years for fathers (6 years between 1984 and 1989 and sons (5 years between 2000 and 2004) when they may report positive annual labor income. Table 3 shows information on the number of years that the fathers and sons have positive annual labor income. Using a sample of son-father pairs, Table 3 suggests that a vast majority of native and immigrant fathers have positive annual labor income for all 6 years $(92 \%$ of native-born fathers and $88 \%$ of foreign-born fathers); whereas it appears that only $43 \%$ of the native sons and $34 \%$ of immigrant sons have positive annual labor income for all 5 years. This evidence is reasonable since it is possibly that some of the sons are unemployment for young people are high in Germany. Additionally, Table 3 points out that the percentage of immigrant sons with one or two years of positive income is higher than native sons with same years of information, where 
the corresponding numbers are $37 \%$ and $27 \%$ for immigrant sons and native sons, respectively.

\section{4.b. Micro Census Data}

The Microcensus Scientific Use File ${ }^{5}$ enables me to include children that are residing in the same household with their parents. In this paper, I mainly use fathers who have children between 5 and 18 years old those living in the same household between 1989 and 1991. Additionally, I construct the sons sample by using individuals who are between 20 and 33 years old between 2000 and 2004. Therefore, I claim that these sons are most probably the sons of the fathers' sample that I obtain for 1989 to 1991. This assumption seems plausible; hence it appears that more than $90 \%$ of children under 18 years of age are residing in the same household with their parents ${ }^{6}$.

A drawback from the Census is that it is not possible to identify the nationality of approximately 50,000 people residing in the Federal Republic of Germany. These people are referred as "others" in the Census data, thus we can not distinguish their nationalities. Fortunately, the faction of that group is less than $1 \%$ of those with nationalities other than German and we can successfully identify 20 countries in the 1989 and 1991 censuses.

Table 4.a. decomposes the characteristics of native and immigrant men by whether individuals have children; have children between 5 and 18 years of age or do not have child at all. Additionally, Table 4.b. presents the summary statistics for the second generation immigrants and their native counterparts by different age ranges. It appears

\footnotetext{
${ }^{5}$ Information on data sources and extracts is provided in the data appendix.

${ }^{6}$ Source: Schimpl -Neimanns (2002:7)
} 
that native and immigrant fathers with children and with children between 5 and 18 years of age have similar average age, whereas both native and immigrant men without any child are older.

Unfortunately, Microcensus data does not contain information regarding wages of the individuals; instead it has information concerning "main source of income". I identify full-time workers as those who report the employment earnings as the main source of income and work at least 30 weeks per year and 30 hours per week like in Zimmerman (1992) and I use the income information for these individuals as a proxy for their earnings. An additional concern is that income information is reported in intervals in the Microcensus. There were 18 brackets from 1989 to 1991 and 24 brackets in 2000 and 2001. Thus this variable was converted into a continuous variable by taking the average of the interval endpoints. Finally, all income measures were deflated using the CPI. From Table 4.a., it seems that the native fathers have higher income levels compared to immigrant fathers regardless of having children or not. Further, both native and immigrant men with children 5 years of age or older have the highest levels of income among all groups, although their average age is less than for men without children. Similarly, from Table 4.b., it appears that although the native sons earn more than the second generation immigrants in all age groups; the income gap is relatively small particularly for individuals in the 20-33 age range.

As an alternative, I construct adjusted earnings by regressing log monthly income on nationality dummies, state dummies, age and age-squared interacted with nationality for the immigrants. The reason for including the interaction terms is to control for differences in age-earnings profiles across different nationalities. I then calculate 
predicted income for immigrant fathers that report employment as their main source of income by using the means of the demographic variables of each nation. Likewise, for the second generation sons, I construct adjusted income by regressing income on the same covariates by using sample means of corresponding variables from 2000 to 2004 censuses. The average adjusted income is again higher for both native fathers and sons. Note, however, that the income gap diminishes between native and immigrant sons considerably after the adjustment.

The percentage of immigrants who are fulltime workers varies considerably across different countries of origin. Table 5 displays the percentage of full-time working male immigrants for 20 different nationality groups. Turks constitute around $40 \%$ of the entire immigrant population in all different specifications, except for the first generation immigrants without children. The other "guest worker" countries, Ex-Yugoslavia, Italy, Greece, and Spain follow Turkey in terms of percentages.

As a final point, the Microcensus data also provides information on the highest secondary school degree acquired, and information related to the type of vocational training that the individual attended. These two variables allow us to construct the years of education variable that is comparable to the years of education variable in GSOEP data. Tables 4.a. and 4.b. illustrate that the second generation is less likely to complete the basic academic route, Hauptschule, relative to their fathers and the average years of schooling increases for the second generation in all age ranges. Detailed information on the construction of the education variable is presented in the Appendix. 


\section{Results on Intergenerational Earnings Mobility}

\section{5.a. Earnings Elasticity}

To explore intergenerational elasticity of earnings, I used the log annual earnings for the previous year and the current monthly earnings from the GSOEP. Annual labor earnings include wages and salary from all employment including training, primary and secondary jobs, and self-employment, plus income from bonuses, overtime, and profit sharing. I eliminate observations if an individual goes to school or gets training in all years. I work with the natural logarithm of earnings to correct for the non-normality of the earning distribution and to decrease the influence of outliers.

In this paper, I used individuals who worked full-time and have positive annual income for at least one year. Also, I disregard earnings while in school, vocational training, or maternity leave. Vocational training pays low and regulated wages which are not suitable measures for long-run status. I exclude yearly observations for which yearly earnings are non-positive or missing from the analysis, as is commonly done in most of the existing studies.

First, I estimate equation (2) by using log yearly income in order to consider fathers and sons at similar stages in their life-cycles. Then, I obtained residuals and take multi-year average of residuals in order to get a closer measure of permanent income and to take away the transitory component of earnings. Annual earnings for the sons are averaged over the five survey years from 2000 to 2004, while annual earnings for the fathers are averaged over six-years from 1984 to 1989. I assume that both fathers' and sons' transitory error components follow AR (1) process. Averaging son's income and 
father's income should improve the ratio of signal to total variance, and this will reduce the error in variables bias. Most previous research uses single year of sons' income and multiple year of fathers' income to correct this bias. However, if fathers' transitory components and sons' transitory components are correlated, measurement error in the sons permanent income measure will also introduce biases in the elasticity estimates.

For Germany, if we use single year of sons' income and 6 year average of fathers' income then estimates of $\beta$ range from 0.17 to 0.31 for natives and 0.15 to 0.34 for immigrants and most of the estimations are insignificant for immigrants. ${ }^{7}$ So using single year to proxy for sons' permanent status can give misleading results. The estimates using multi-year averages for both fathers and sons, shown in Table 6, are 0.20 for natives and 0.23 for immigrants and they are both significant.

In addition, estimates of permanent earnings will suffer from measurement error if the sample contains individuals who have reported earnings only for a small number of years. To eliminate this problem, I increase the minimum number of years for which individuals have valid earnings information to be included in the sample. I construct subsamples with individuals who worked full-time for more than 3 years, 4 years and so on. The second column in table 6 shows estimates with the sub-sample of individuals who have positive income for at least 3 years. The reduction in the downward bias through measurement error is dramatic, especially for immigrants. For the native father-son pairs elasticity increases from 0.21 to 0.25 , whereas for the immigrant father-son pairs the increase is more striking, from 0.23 to 0.37 . The estimations are very similar with the sub-sample of father-son pairs who worked more than 4 years, and more than 5 years. These results show less mobility for immigrants than for natives. In particular, the results

\footnotetext{
${ }^{7}$ Results can be shown upon request.
} 
suggest that an immigrant son is $13 \%$ as likely to have the same income as his grandfather, while a native son is $6 \%$ as likely to have the same income as his grandfather.

However, as discussed below, these estimates of mobility could still be biased because individual mobility may depend not only on the parents' socio-economic status but also on the socio-economic status of those around them, including neighbors and people that one usually interacts with. This is particularly important for immigrants who often grow up in ethnic enclaves and are heavily influenced by those in their ethnic groups (Borjas 1992, 1995).In the next section, I include the socio-economic status of those in one's ethnic group to see how these "ethnic capital" affects the socio-economic status of immigrant sons.

\section{5.b. Ethnic Capital}

Estimates of the Impact of Ethnic Capital using the GSOEP

The OLS regression of second generation immigrants' earnings on parental earnings might substantially underestimate the intensity of the true linkage in earnings across generations, even in the absence of measurement error. Table 7 presents the estimation results for the regressions of children's log annual income on parent's log annual income as well as the ethnic capital variable. Ethnic capital in these regressions is defined as the average of log income for each nationality measured by including not only fathers in father-son pairs but also all working men in the original GSOEP data. Table 7 shows the estimated coefficient of persistence that can be attributed to fathers' status, $\beta_{1}$, and falls slightly from 0.37 to 0.35 after controlling for ethnic capital. At the same time, it 
seems that ethnic capital is one of the essential determinants of children's income since the estimated coefficient of ethnic capital variable, $\beta_{2}$, in children's income equation is 0.81 .

Consequently, we can conclude that ethnic capital plays an important role in determining the skills of the next generation in Germany. As a result, the degree of immobility, which is the sum of "parental capital", 0.35 , and ethnic capital, 0.81 , is not statistically different from 1 . This implies complete immobility of immigrants as a group relative to natives in Germany, although individual immigrants may be doing better than their fathers. Compared to U.S. studies which look at the role of parental and ethnic capital together (Borjas, 1992, 1995), these estimates suggest much less mobility for immigrants in Germany than in the U.S., where there is convergence of immigrant earnings. As noted below, this is also the immobility rate I find when using census data in the following section.

\section{Estimates of the Impact of Ethnic Capital using the Micro-Census}

An analysis of the generational mobility of immigrants using detailed country of origin along these lines is also offered in Borjas (1993) and Card, DiNardo and Estes (2000). I define first generation immigrants as those who immigrated to Germany regardless of the age of arrival. For the most part, I follow Card, DiNardo and Estes (2000). I define second generation immigrants to be those born in Germany born but who are not German nationals and those who migrate to Germany before 6 years of age. Immigrant fathers are drawn from the 1989 and 1991 censuses and restricted to those individuals who have children between the ages of 5 and 18 years. Using regression 
analysis, average values of $Y_{\mathrm{oj}}$ are calculated for each country of origin for individuals matching these criteria. Correspondingly, second generation immigrants consist of nonGerman individuals between 16 and 34 years of age (corresponding to children who were between 5 and 18 in the 1989 to 1991 Censuses) in any of the censuses in 2000 to 2004 . Average values of $Y_{1 j}$ are calculated for each country for respondents who report their own and their fathers' nationality.

For immigrant fathers, we constructed adjusted earnings by regressing log monthly income on country of nationality dummies, state dummies, age and age-squared interacted with dummies for country of nationality. The reason to include the interaction terms is to control for differences in age-earnings profiles across countries of origin. We then calculate predicted income by using the means of the demographic variables of each nation and generation observed in the sample. I include all natives, first and second generation male immigrants, who report that their main income source comes from work. For the second generation sons, we constructed adjusted income by regressing on to the same variables but calculate the predicted income for means of variables from the sample of 2000 to 2004 Censuses.

Table 8 presents estimates of equation (6) using least squares for different samples. They differ according to the age of these individuals, and according to the age and family characteristics of their potential fathers who are drawn from the 1989 and 1991 Censuses. The first row uses a sample selection rule as similar as possible to that used by Card, DiNardo and Estes (2000). This is the broadest possible definition of second generation immigrants and their potential fathers. For possible fathers, I use all working males between 25 and 65 years and who have children from the 1989 and 1991 
Censuses. For possible immigrant sons, I used all working males between 20 and 45 years old and who have non-German nationality in the 2000 to 2004 annual Censuses. The sons' predicted earnings at the mean of characteristics are the outcome of interest. Card, DiNardo and Estes (2000, table 6.7) report an elasticity of 0.44 for a fathers in 1940 and sons in 1970, and 0.62 for fathers in 1970 and sons in 1995. As they note, these are in the range of reported estimates for the general US population. By contrast, I find an elasticity of 1.12 for Germany, which is substantially higher than the one found for the U.S. using a similar sample. In row 2, I report results from a narrower sample, where the ages of sons is narrowed to include only 20 to 33 years olds from the 2000 to 2004 Censuses and who are potential fathers as they have children between 5 and 18 years of age in the 1989 through 1991 Censuses. The reason for narrowing down the group is that Censuses which have only 15 years differences between each other are available for estimations. This sample offers the greatest possibility of linking adult sons with their potential fathers. However, there may still be a disconnect between fathers and sons in this sample if some immigrants and their families in the 1989 or 1991 sample left the country before 2000 or sons already left home before 18 years old. The estimate of $\beta$ obtained with this sample is 0.88 , suggesting that the point estimates from the broader sample in row 1 likely overestimates the persistence rate. When I narrow farther the sample to sons older than 25 , the persistence rate is even lower at 0.73 .Figure 1 presents a scatter plot of the 20 data points and the adjusted log annual income of second generation sons against the adjusted log income of first generation immigrant men. Like the estimation results, inspection of this figure suggests strong links between the earnings of immigrant fathers and the outcomes of their children. 


\section{Comparison with Results from other Studies}

There are numerous reviews ${ }^{8}$ summarizing the cross-country comparisons of the degree of generational earnings mobility. In these studies, the results may substantially differ between and within countries due to a number of reasons. Differences in data and methodologies are likely to account for most of the variation. First, the age of sons and parents at which incomes are obtained and measure of permanent income used (e.g., annual income, monthly wage, hourly wage, or total family income) differ across studies. Table 9 shows the results on the earnings elasticity for different countries from other studies which use the same estimation method and similar selection methods to my paper. Most of the studies show that around $40 \%$ of parental earnings advantage passes on to the children in U.S. One exception for this is Couch and Dunn (1997). By using similar selection rules for sons and fathers, they find an income persistence rate of 0.13 for the U.S. and 0.11 for Germany. This persistence rate for Germany is very similar to estimates by Grawe (2004) and Lillard (2001). Similarly, for Scandinavian countries, the persistence rate varies between 0.10 and 0.20 , whereas, for Canada and UK, it is estimated to be 0.20 .

As noted above, my analysis estimates persistence rates of 0.25 and 0.37 for natives and immigrants, respectively. This result is considerably higher than most of the estimates for Germany found in previous studies, and slightly lower than U.S. estimates for natives. The reasons for this difference are twofold. First, as stated earlier, the sons' average age in my sample is mid-thirties, so my sample of sons is older than those used in previous studies of intergenerational mobility in Germany. Second, previous studies examine intergenerational mobility in Germany using current monthly income, whereas I

\footnotetext{
${ }^{8}$ Solon (2002,1999), Mayer (2002), Jencks (2004), Corak (2006)
} 
use annual labor income to obtain permanent income. Using an older sample of sons is preferable because it captures sons at stages closer in their careers to their fathers. Also, using annual income rather than monthly income gives a measure that is closer to permanent income, as monthly income may be subject to transitory shocks. Both of these contribute to reducing problems with measurement error and obtaining more accurate result.

\section{Channels of Intergenerational Transmission of Inequality}

Socio-economic status can be passed on from generation to generation through a number of channels. The most obvious channel through which parents affect their children's income potential is through their educational attainment. Parents with greater educational attainment may devote more time to their children's education if a substitution effect dominates but less time if an income effect dominates. Also, the educational attainment of those in one's reference group may affect one's educational attainment by increasing resources and by changing one's expectations of the returns to education. However, there are also other channels through which socio-economic status will be passed on. In particular, a regressive tax system will help to perpetuate the structure of inequality, but a progressive tax system will, on the contrary, provide greater mobility. The more progressive tax system in Germany may help to explain the greater mobility in Germany with respect to parental income. Finally, intergenerational mobility may be reduced if jobs are passed on through networks within occupations or through unions. In this case, not only the probability of getting a job but also the quality of jobs 
will be passed on from parents to children. In what follows, I explore the importance of these various channels in determining income persistence in Germany.

\section{6.a. Education}

I begin by considering the intergenerational transmission of education, to gauge the importance of education in determining income persistence across generations. However, to understand the intergenerational transmission of education better, it is important to first describe the German educational system. In Germany, children usually begin school in the year after they become six and attend a four year primary school. After they finish the fourth grade, the German education system channels students into three types of secondary schools, which differ in terms of academic content. The lowest level or basic route of secondary school (Hauptschule), intends to give students a schoolleaving certificate after grade 8 or 9 . The main scope of this type of secondary schools is basically to equip students with some vocational skills and prepare them for an apprenticeship. The second type of secondary school, the middle level (Realschule) ends after grade 10 and is much more academically oriented than the basic school. In the middle level students also enter an apprenticeship or a school based vocational training after finishing school. And the last type of secondary schools is the Gymnasium, which has the highest academic level among the three. The Gymnasium prepares students for the university entrance exam (Abitur) after grade 13 or gives them a chance to take a lower level qualification after grade 12, called Fachhochschulreife, which allows school leavers to attend a polytechnic. 
Students in the different secondary schools will attend different types of high schools and colleges on the basis of their route initiated at the end of grade four. The basic difference between the German and American education systems lies in the concept of this initial placement. The student is placed in one of these three types of schools and this placement tends to be permanent, and the mobility, basically the upward mobility is very rare (Pischke, 1999). The decision of the type of secondary school bases on the different factors such as formal exams, primary school grades, recommendations by the primary school teacher, and parental choice. The selection process might differ between states and over time.

Table10 shows the results for the regression of the son's completed number of years of education on father's years of education. There is substantial evidence suggesting that the human capital of the parents is essential in determining the child's human capital. The estimation results illustrate that approximately 47 percent and 30 percent of the parental human capital is transmitted to the child for the natives and the immigrants respectively. Similarly, for the more constrained subset that includes only individuals with information on education for at least 3 years, I find that second generation natives inherit 49 percent of their parents' education attainment, whereas second generation immigrants are more mobile in terms of years of schooling, since they only seem to inherit 34 percent of their parents' human capital. These findings coincide with what one may expect for Germany, since the public education system in Germany provides less expensive and of more equal quality of education is provided to individuals in all income groups. To offer equal educational opportunities to everyone, the poor families are subsidized by the combination of taxes and educational transfer revenues taken from high 
income families. This feature of the German education system enables children of the less advantageous group to get better education opportunities and therefore, is expected to generate more upward mobility than the U.S. education system..

Note, however, that although second generation immigrants are more mobile in terms of their education, they continue to resemble income disadvantages of their parents. The reason for this puzzling result could be two-fold. First, even though it seems that the second generation immigrants are doing better than their parents in terms of education, it is worth to note that their completed years of schooling are less than that of native sons. According to GSOEP, it appears that second generation immigrants attain 10.82 years of schooling, 1.8 years more from that of their parents whereas second generation natives get 12.3 years of schooling or 0.8 more years than their parents. Also, the parallel results can be obtained by using Microcensus data. Thus, even though the immigrant sons are more upward mobile, they still remain behind in terms of completed years of education. Second, it is important to note that our analysis is based on the completed years of schooling and the potential differences in quality of education related to types of schools individuals attend would be a problem. Among the first generation immigrants, 65 percent of the individuals complete only lowest level of high school, "Hauptschule", compare to 51 percent for the corresponding native generation. However, the fraction of those who complete only Hauptschule decreases drastically to 18 percent for native sons, and to 35 percent for the second generation immigrants.

Contrary to the results on income mobility, immigrants appear to be more mobile than natives in terms of years of schooling. The correlation of years of schooling is around 0.5 for natives but 0.2 for immigrants. Therefore, as a conclusion, education 
cannot explain the higher persistence rate of income for immigrants' than for natives. If anything, education appears to help in equalizing immigrants with natives.

I would like to find out the extent to which the effect of ethnic capital on intergenerational mobility is driving the education results. Thus, to see the effect of ethnic capital on education of immigrant children, I include ethnic capital as a control variable into education estimation. Table 7 presents, with the inclusion of ethnic capital, the coefficient on parental input changes slightly from 0.33 to 0.31 . This finding suggests that ethnic capital is not significantly affecting children's education. To control for the validity of this result, I also repeat the estimation using Microcensus data. Table 8 displays the estimation results for Microcensus data. From Table 8, it appears that the persistence rate is 0.33 when fathers who have children between 5 and 18 years old are used in estimations. The persistence rate is equal to the sum of parental and ethnic capital in the estimations using Microcensus data. Disentangling the persistence rate using GSOEP suggests that the parental capital is around 0.35 and ethnic capital is almost negligible in determining the child's human capital. ${ }^{9}$

\section{6.b. Relative income position}

Contrary to the previous section which analyzes gross income at the individual level, in this section I use gross and net income information calculated at the household

${ }^{9}$ My results contrast with the results in previous studies. Couch and Dunn (1997) use GSOEP data and find that the intergenerational elasticity of education is 0.19 for Germany, which is considerably smaller than my estimates. However, Dustman (2005) finds a persistence rate of education of 0.42 for natives and around 0.10 but insignificant for immigrants. For the U.S., Borjas $(1992,1995)$ estimates a persistence rate of parental capital of 0.25 and of ethnic capital of 0.20 , or an overall persistent rate of 0.45 , which is higher than my estimates. 
level. Father's earnings might not fully capture the economic resources of the family, particularly for low income fathers. The assumption underlying this approach is that all members of a specific household pool their resources and share the utility of a given household income. Consequently, information about the various income components of a specific household is ascribed to all members of that household, regardless of age or individual income performance. The sum of employment income, capital income, and private transfers represents gross household income. Adding old age pensions and public transfers, and subtracting taxes and social security contributions yields a measure of net household income. I deflate all income measures to Euro units in 2001 using price indices. In order to adjust for differences in household size and composition, I divide gross and net household income by the modified OECD equivalence scale-which gives weights of 1.0 to the head, 0.5 to other adult household members, and 0.3 to each childto obtain individual before and after tax income.

I obtain total mean of population by multiplying weights and before (after) tax incomes of all individuals between 20 and 45 years old in the sample, and then by dividing with the sum of their weights. This weighted mean of before (after) tax income of population is equated to 100, then individual before (after) tax income is ranked relative to the mean for the total population in each year to obtain relative gross and net income.

Table 10 shows results for the regression of the relative gross and net income on father's relative gross and net income. In my estimations, I only used sons who no longer live with their parents. The estimation results for relative gross and net income illustrate that persistence rate is approximately 0.5 for immigrants while 0.3 for natives. These 
results suggest higher persistence for natives and immigrants once the son's household income is considered rather than the individual income. This probably has to do with assortative mating and the fact that son's tend to marry people like them. It is also interesting to contrast the results using gross vs. net income to try to get at the importance of the tax system. Comparisons for natives do not seem to show significant differences, but results for immigrants suggest lower persistence when net income is considered rather than gross income. This suggests that the tax system in Germany appears to help immigrants in equalizing their status relative to natives.

\section{6.c. Occupation}

GSOEP provides information on father's occupation when sons were aged 15, and publishes an index of occupational prestige computed according to the technique proposed by Ganzeboom and Treiman (1996). The Treiman standard international occupational prestige score varies from 13 to 78 . Larger values indicate higher occupational prestige, and it is highly correlated with earnings. There are three measurement problems with the occupational prestige measure. First, we only have one observation on (when the child was aged 14 or 15); second one, the data of parents are

obtained from adult children and not from the parents themselves; and finally, a misclassification error may arise when a new occupation is observed or an old occupation disappears.

Table 10 also shows the results for the regression of occupation index on father's occupation index. The estimation results illustrate that persistence rate is approximately 
0.2 for natives which is very close to the income persistence rate as expected, and for immigrants persistence rate is close to zero but insignificant, and the number of observation is too small to make exact conclusions.

\section{Conclusion}

This study credibly documented that the extent of the intergenerational mobility in terms of permanent income is less for immigrants from that of natives in Germany. Using both GSOEP, a long panel that over-samples immigrants, and German Microcensus data reveal that although the immigrant sons may be doing better than their fathers, they are still more inclined to inherit the income disadvantage of their families compared to natives. Alternatively, it is likely that the family income constructed by only using father's earnings might underestimate the potential sources of the entire family. Therefore, gross and net income provided at the household level may reflect the extent of intergenerational mobility more precisely. I find evidence suggesting that for the relative gross and net income status, the immigrant sons tend to perpetuate their fathers' status relative to native sons as well. Note however that, these results suggest higher persistence for natives and immigrants once the son's household income is considered rather than the individual income.

As stated in Borjas (1992, 1995), the OLS regression of second generation immigrants' earnings on parental earnings might substantially underestimate the intensity of the true linkage in earnings across generations. Thus, not only the parents' socioeconomic status but also the ethnic environment those parents reside in as well as the language, culture and norms of the ethnic enclave in which the children are raised would 
potentially impact the extent of the intergenerational mobility of immigrant generations. Consequently, inclusion of ethnic capital suggests that ethnic capital plays an important role in determining the skills of the next generation in Germany. The persistence rate which compromise of parental capital and ethnic capital reveals that the immigrant generations in Germany are almost immobile as a group relative to natives in Germany in terms of permanent income. Hence, the persistence rate is not statistically different from unity for immigrants. Compared to U.S. studies which look at the role of parental and ethnic capital together (Borjas, 1992, 1995), the findings that also include ethnic capital imply much less mobility for immigrants in Germany than in the U.S., thus divergence of immigrant earnings in Germany rather than convergence.

The investigation of the channels that might potentially help immigrant sons to catch up to natives enhances our understanding of intergenerational mobility in Germany. The most obvious channel through which parents impact their children's income potential is through their educational attainment. It appears that even though the immigrants are less mobile relative to natives in terms of income, immigrant sons are less likely to inherit their fathers' educational attainment compared to the native second generation. This result suggests that if anything else, education definitely offers opportunities to immigrant sons to overcome their parents' disadvantaged status and to attain comparable levels of earnings as natives. The other potential channel worth mentioning is the progressive tax system in Germany, since the more progressive tax system in Germany may provide less income inequality between natives and different ethnic groups. The comparison of gross versus net relative income for natives do not seem to show significant differences, but results for immigrants reveals lower persistence when net 
income is considered rather than gross income. This suggests that the tax system in Germany appears to help immigrants in equalizing their status relative to natives. Finally, intergenerational mobility may be reduced if jobs are passed on through networks within occupations or through unions. In this case, not only the probability of getting a job but also the quality of jobs will be passed on from parents to children for natives.

These results suggest that in spite of the more egalitarian and less expensive structure of the German education system as well as more progressive German tax scheme, it seems that immigrant generations are "stuck" in their neighborhoods and they are far away from moving with natives. These findings reveal that channels other than education and tax system should be considered to improve permanent status of immigrants over generations in the long run. 


\section{APPENDIX}

\section{GSOEP}

DIW Berlin, the German Economic Institute, administers the GSOEP. It is a longitudinal database that started in 1984 with a sample of about 4,528 households with 12,245 respondents, 3,000 of whom were guest workers from Turkey, Italy, the former Yugoslavia, Spain and Greece. The samples of the GSOEP were expanded in several years. The first two expansions occurred after unification, when the survey was extended to East Germans and immigrants from other countries, especially ethnic Germans $(4,453$ new respondents in 1990) and when East Europeans were included to the database in 1995 (1,078 new respondents). Moreover, in 1998, a new sample was selected from the population of private households in Germany. In 2004, the last year for which the data is available, the GSOEP contained information on 22,019 people living in 11,803 households.

In the GSOEP, interviewers do face-to-face interviews with all members of a given survey household aged 16 years and over. Thus, there are no proxy interviews for adult household members. The reduction in the population size for all individual samples is mainly the result of person-level dropouts, refusals, moving abroad, etc. However, the sample size increases because of new persons moving into already existing households and children reaching the minimum respondent's age of 16. Also, a person is followed up even after moving out of the household. Thus, this allows us to establish links even when they do not live in the same household any more.

The annual labor earnings examined in Table 1 include wages and salary from all employment including training, primary and secondary jobs, and self-employment, plus 
income from bonuses overtime particularly 13 th month pay, 14th month pay, Christmas bonus pay, holiday bonus pay, miscellaneous bonus pay and profit sharing.

\section{Micro Census Data}

The $1 \%$ Microcensus is a large, representative sample of the population containing demographic information and labor market data. It is a random sample where all households have the same probability to be selected. Out of the whole country, certain regions are chosen, and all households and persons get interviewed in this region. In total approximately 370,000 households with 820,000 people are interviewed in the 2004 Microcensus. Additionally, the 2004 Microcensus contains information for 160,000 people of about 70,000 households who live in the new states and East Berlin.

The Microcensus was conducted once a year until 2004 and it is generally in the form of face-to-face interview of respondents by an interviewer. A quarter of all households in the sample get replaced every year. Consequently, each household stays in the sample for 4 years. In addition, the response rate in the Microcensus is regularly very high, almost 98 percent. In particular, the information associated with employment, applies to the defined reference week, which usually described as the last week of April without any holiday. Accordingly, employed persons are all those who are 15 and older and who have worked at least one hour in the reference week.

I use subsample of Microcensus, Microcensus Scientific Use File, which is a subsample of the Microcensus available for use by researchers. Microcensus Scientific Use File is a $70 \%$ subsample of the original Microcensus that anonymizes all 
individuals. This factually anonymized subsample was drawn as a systematically random selection from the original data by the Federal Statistical Office. 


\section{References}

Altonji, R.G. and Dunn, T.A., (1991) "Relationships among the Family Incomes and Labor Market Outcomes of Relatives” Res. Labor Econ. 12, pp. 269-310

Atkinson, A. B., (1981) "On Intergenerational Income Mobility in Britain", Journal of Post Keynesian Economics 3, no. 2, pp. 194-217

Becker, G. and Tomes, N. (1986) "Human Capital and Rise and Fall if Families" Journal of Labor Economics 1986, Vol.107, pp.123-150

Behrman, Jere and Taubman, Paul, (1976) "Intergenerational Transmission of Income and Wealth.” American Economic Review 1976, Vol.66, No.2, pp.436-40

Björkland, A. and Jäntti, M., (1997) "Intergenerational Income Mobility in Sweden Compared to the United States", American Economic Review 1997, Vol. 87, pp.10091018

Borjas, George J. (1992) "Ethnic Capital and Intergenerational Mobility" The Quarterly Journal of Economics, 1992, Vol.107, No.1, pp.123-150

Borjas, George J., (1993) "The Intergenerational Mobility of Immigrants", Journal of Labor Economics, 1993, Vol. 11, No.1, pp.113-135

Borjas, George J., (1994) "Long-Run Converges of Ethnic Skill Differentials: The Children and Grandchildren of the Great Migration" Industrial and Labor Relations Review, 1994, Vol. 47, No.2, pp.553-573.

Borjas, George J, (1994b) "The Economics of Migration", Journal of Economic Literature, Vol.32, pp.1667-1717

Borjas, George J. (1995), "Ethnicity, Neighborhoods, and Human Capital Externalities," American Economic Review, Vol.85, No.3, pp.365-390

Bratberg Espen, Øivind A. Nilsen, and Kjell Vaage (2003), "Assessing Changes in Intergenerational Earnings Mobility”, IZA Discussion Paper, No.797

Card, D., J. DiNardo, and E. Estes (2000), "The More Things Change: Immigrants and the Children of Immigrants in the 1940s, the 1870s and the 1990s" in George Borjas, ed., Issues in the Economics of Immigrants, Chicago: University of Chicago Press.

Corak, M. and Heisz, A. (1999) "The Intergenerational Income Mobility of Canadian Men”, Journal of Human Resources, vol. 34, pp.504-33 
Corak, M. ed. (2004), "Generational Income Mobility in North America and Europe", Cambridge: Cambridge University Press.

Corak, M. (2006) "Do Poor Children Become Poor Adults? Lessons from a Cross Country Comparison of Generational Earnings Mobility", IZA Discussion Paper, No.1993

Couch, Kenneth A. (1994), "High School Vocational Education, Apprenticeship, And Earnings: a Comparison of Germany and the United States" Vierteljahrshefte Zur Wirtschaftsforschung 1 (2): 10-18

Couch, Kenneth A. and Thomas A. Dunn. (1997), "Intergenerational Correlations in the Labor Market Status: A comparison of the United States and Germany", Journal of Human Resources, 32(1): 210-232

Daerden L., and Machin, S. and Reed H. (1997), "Intergenerational Mobility in the UK", Economic Journal, Vol.107, pp.47-64

Dustmann, Christian(2005), “ Intergenerational Mobility and Return Migration: Comparing sons of foreign and native born fathers", CReAM Discussion Paper No.07/05

Freeman, Richard B. (1981), "Black Economic Progress after 1964: Who Has Gained and Why?" In Studies in Labor Markets, edited by Sherwin Rosen, Chicago: University of Chicago Press (for NBER),

Grawe Nathan (2004), "Intergenerational Mobility for Whom? The Experience of High and Low Earning Sons in International Perspective. "in M.Colak(ed) Generational Income Mobility in North America and Europe, Cambridge University Press

Haider, S. and G. Solon. (2006) "Life-Cycle Variation in the Association between Current and Lifetime Earnings", American Economic Review, 96, pp 1308-1320.

Hauser, Robert M.; Sewell, William H.; and Lutterman, Kenneth G. (1975), "Socioeconomic Background, Ability and Achievement" In Education, Occupation and Earnings, edited by William H. Sewell and Robert M. Hauser. New York: Academic Press

Inoue, A. and Gary Solon, (2005) "Two-sample instrumental variables estimators", NBER Technical Working Paper, No.311

Lillard, D. R. (2001) "Cross-National Estimates of the Intergenerational Mobility in Earnings" Vierteljahrshefte zur Wirtschaftsforschung 70. Jahrgang, Heft 1/2001, S. 5158

Mazumder, Bhashkar (2001) "Earnings Mobility in the US: A New Look at International Inequality", Department of Economics, University of California, Berkley 
Minicozzi, A. L. (2003) 'Estimation of Sons' Intergenerational Earnings Mobility in the Presence of Censoring', Journal of Applied Econometrics, Vol. 18, No.3, pp. 291-314

Han, Song \& Mulligan, Casey B, (2001) "Human Capital, Heterogeneity and Estimated Degrees of Intergenerational Mobility", Economic Journal, Royal Economic Society, vol. 111(470), pages 207-43, April.

Österbacka, Eva (2003), "Family Background and Economic Status in Finland", Scandinavian Journal of Economics, Vol.103, pp.467-84

Osterberg, Torun (2000) "Intergenerational Income Mobility in Sweden: What do TaxData Show?" Review of Income and Wealth, Series 46, pp.421-36

OECD (1999a), Trends in International Migration, Annual Report, 1999 Edition, Paris:

The Organization for Economic Cooperation and Development.

Solon, Gary R. (1989), "Biases in the Estimation of Intergenerational Earning Correlations" Review of Economics and Statistics 71, pp 172-174

Solon, Gary R. (1992), "Intergenerational Income Mobility in the United States" American Economic Review 82(3): 393-408

Solon, Gary R. (1999), "Intergenerational Mobility in the Labor Market", in (O. Ashenfelter, and D. Card eds.), Handbook of Labor Economics, Vol. 3A, pp. 1761-1800, Amsterdam: North-Holland

Solon, Gary R. (2002), "Cross-Country Differences in Intergenerational Earnings Mobility", Journal of Economic Perspectives, vol. 16(3), pp. 59-66.

Zimmerman, David J. (1992), "Regression Toward Mediocrity in Economic Stature" American Economic Review 82(3): 409-29 
TABLE 1:Descriptive Statistics for Natives and Immigrants by using GSOEP

\begin{tabular}{|c|c|c|c|c|}
\hline \multirow[b]{2}{*}{$\underline{\text { Variable }}$} & \multicolumn{2}{|c|}{ Fathers } & \multicolumn{2}{|c|}{ Sons } \\
\hline & $\underline{\text { Native }}$ & Immigrants & $\underline{\text { Native }}$ & $\underline{\text { Immigrants }}$ \\
\hline Age & $\begin{array}{l}44.63 \\
(9.15)\end{array}$ & $\begin{array}{l}45.81 \\
(8.49)\end{array}$ & $\begin{array}{l}30.82 \\
(7.18)\end{array}$ & $\begin{array}{l}30.88 \\
(7.30)\end{array}$ \\
\hline Years of Schooling & $\begin{array}{l}11.39 \\
(2.32)\end{array}$ & $\begin{array}{c}9.05 \\
(1.90)\end{array}$ & $\begin{array}{l}12.26 \\
(2.73)\end{array}$ & $\begin{array}{l}10.82 \\
(2.23)\end{array}$ \\
\hline Log(yearly income) & $\begin{array}{l}10.28 \\
(0.44)\end{array}$ & $\begin{array}{l}10.04 \\
(0.29)\end{array}$ & $\begin{array}{l}10.04 \\
(0.79)\end{array}$ & $\begin{array}{l}10.03 \\
(0.65)\end{array}$ \\
\hline Hourly Wage & $\begin{array}{c}16.57 \\
(12.40)\end{array}$ & $\begin{array}{l}12.92 \\
(6.01)\end{array}$ & $\begin{array}{l}12.81 \\
(7.55)\end{array}$ & $\begin{array}{l}12.05 \\
(6.15)\end{array}$ \\
\hline Occupational Index & $\begin{array}{c}42.75 \\
(12.82)\end{array}$ & $\begin{array}{l}33.61 \\
(9.06)\end{array}$ & $\begin{array}{c}43.90 \\
(11.74)\end{array}$ & $\begin{array}{l}38.28 \\
(9.72)\end{array}$ \\
\hline Relative Gross Income & $\begin{array}{c}95.26 \\
(45.98)\end{array}$ & $\begin{array}{c}78.49 \\
(29.83)\end{array}$ & $\begin{array}{l}117.39 \\
(58.69)\end{array}$ & $\begin{array}{c}95.14 \\
(55.05)\end{array}$ \\
\hline Relative Net Income & $\begin{array}{c}94.27 \\
(35.33)\end{array}$ & $\begin{array}{c}77.10 \\
(22.74)\end{array}$ & $\begin{array}{c}108.06 \\
(42.37)\end{array}$ & $\begin{array}{c}91.45 \\
(39.72)\end{array}$ \\
\hline $\mathrm{N}$ & 518 & 207 & 647 & 269 \\
\hline
\end{tabular}


TABLE 2: Distribution of Fathers by Number of Sons

\begin{tabular}{|c|c|c|c|c|}
\hline \multirow[b]{2}{*}{ Number of Sons } & \multicolumn{2}{|c|}{ natives } & \multicolumn{2}{|c|}{ Immigrants } \\
\hline & Number & Percent & Number & $\underline{\text { Percent }}$ \\
\hline 1 & 408 & 78.72 & 156 & 77.66 \\
\hline 2 & 95 & 18.38 & 41 & 18.21 \\
\hline 3 & 13 & 2.51 & 9 & 3.78 \\
\hline 4 & 1 & 0.19 & 1 & 0.34 \\
\hline 5 & 0 & 0 & & \\
\hline 6 & 1 & 0.19 & & \\
\hline Total \# of Sons & 647 & 100 & 269 & 100 \\
\hline Total \# of Fathers & 518 & & 207 & \\
\hline
\end{tabular}

TABLE 3:Distribution of Fathers and Sons by Number of Years with Positive Annual Labor Income

\begin{tabular}{|c|c|c|c|c|c|c|c|c|}
\hline \multirow[b]{3}{*}{ Number of Years } & \multicolumn{4}{|c|}{ Fathers } & \multicolumn{4}{|c|}{ Sons } \\
\hline & \multicolumn{2}{|c|}{ Natives } & \multicolumn{2}{|c|}{ Immigrants } & \multicolumn{2}{|c|}{$\underline{\text { Natives }}$} & \multicolumn{2}{|c|}{$\underline{\text { Immigrants }}$} \\
\hline & Number & Percent & Number & Percent & Number & Percent & Number & $\underline{\text { Percent }}$ \\
\hline 1 & 1 & 0.19 & 0 & 0 & 99 & 15.3 & 50 & 18.59 \\
\hline 2 & 4 & 0.77 & 5 & 2.4 & 81 & 12.52 & 48 & 17.84 \\
\hline 3 & 13 & 2.51 & 3 & 1.44 & 90 & 13.91 & 37 & 13.75 \\
\hline 4 & 7 & 1.35 & 3 & 1.44 & 100 & 15.46 & 42 & 15.61 \\
\hline 5 & 15 & 2.9 & 14 & 6.73 & 277 & 42.81 & 92 & 34.2 \\
\hline 6 & 477 & 92.26 & 183 & 87.98 & & & & \\
\hline Total \# of Individuals & 518 & & 207 & & 647 & & 269 & \\
\hline
\end{tabular}


TABLE 4a: Characteristics of Natives and First Generation Immigrants using Microcensus

\begin{tabular}{|c|c|c|c|c|c|c|}
\hline \multirow[b]{3}{*}{ Variables } & \multicolumn{6}{|c|}{ "1989-1991 censuses } \\
\hline & \multicolumn{2}{|c|}{ Without children } & \multicolumn{2}{|c|}{ With children } & \multicolumn{2}{|c|}{$\begin{array}{l}\text { with children age btw } \\
5-18\end{array}$} \\
\hline & $\frac{\text { Natives }}{(1)}$ & $\frac{1 \mathrm{stGen}}{(2)}$ & $\frac{\text { Natives }}{(3)}$ & $\frac{1 \mathrm{stGen}}{(4)}$ & $\frac{\text { Natives }}{(5)}$ & $\frac{1 \mathrm{stGen}}{(6)}$ \\
\hline Fraction of Population & 0.43 & 0.02 & 0.51 & 0.04 & 0.24 & 0.02 \\
\hline Mean Age & 46.06 & 42.38 & 41.75 & 40.80 & 41.24 & 41.71 \\
\hline Mean Educ. Year & 11.72 & 11.37 & 11.79 & 10.78 & 11.94 & 10.67 \\
\hline Fraction "Hauptschule" & 0.49 & 0.55 & 0.53 & 0.63 & 0.51 & 0.65 \\
\hline Fraction of Worker & 0.69 & 0.73 & 0.87 & 0.84 & 0.93 & 0.86 \\
\hline Hours Worked in Week & 41.40 & 40.70 & 42.30 & 40.40 & 42.88 & 40.67 \\
\hline Income & $1,228.00$ & $1,064.03$ & $1,433.60$ & $1,229.80$ & $1,571.20$ & $1,332.80$ \\
\hline Adjusted Income & $1,401.20$ & $1,252.90$ & $1,598.16$ & $1,398.80$ & $1,624.20$ & $1,374.60$ \\
\hline $\mathrm{N}$ & 106,139 & 5,656 & 128,256 & 8,739 & 59,343 & 5,844 \\
\hline
\end{tabular}

Notes: : Each sample consist of males between 25 and 65 years old drawn from 1989 and 1991 Microcensus. Earnings are deflated using the CPI and expressed in 2001 Euros. Immigrants refer to people who have nationality other than German. Hours worked and income variable is only for men who report the employment payments as the main source of income and work at least 30 weeks per year and 30 hours per week. Adjusted income constructed by regressing log monthly income on nationality dummies, state dummies, age and age-squared interacted with nationality for the immigrants.

TABLE 4b: Characteristics of Natives and Second Generation Immigrants using Microcensus

\begin{tabular}{|c|c|c|c|c|c|c|}
\hline \multirow[b]{3}{*}{$\underline{\text { Variables }}$} & \multicolumn{6}{|c|}{ 2001-04 census } \\
\hline & \multicolumn{2}{|c|}{ age $20-45$} & \multicolumn{2}{|c|}{ age $20-33$} & \multicolumn{2}{|c|}{ age $25-33$} \\
\hline & $\underline{\text { Natives }}$ & 2ndGen. & $\underline{\text { Natives }}$ & 2ndGen. & $\underline{\text { Natives }}$ & 2ndGen. \\
\hline & (1) & (2) & (3) & (4) & $(5)$ & (6) \\
\hline Fraction of Population & 0.58 & 0.01 & 0.26 & 0.01 & 0.16 & 0.01 \\
\hline Mean Age & 33.70 & 28.20 & 26.71 & 25.84 & 29.32 & 28.50 \\
\hline Mean Educ. Year & 12.80 & 12.14 & 12.67 & 12.02 & 12.94 & 12.24 \\
\hline Fraction "Hauptschule" & 0.22 & 0.35 & 0.18 & 0.35 & 0.20 & 0.36 \\
\hline Fraction of Worker & 0.78 & 0.68 & 0.70 & 0.64 & 0.77 & 0.71 \\
\hline Hours Worked in Week & 41.72 & 40.75 & 40.86 & 40.18 & 41.31 & 40.71 \\
\hline Income & $1,892.20$ & $1,590.11$ & $1,497.67$ & $1,452.33$ & $1,702.23$ & $1,654.59$ \\
\hline Adjusted Income & $1,814.98$ & $1,794.81$ & $1,810.90$ & $1,825.29$ & $1,808.11$ & $1,778.64$ \\
\hline $\mathrm{N}$ & 324,015 & 7308 & 145,628 & 5,831 & 94,065 & 3,478 \\
\hline
\end{tabular}

Notes: Each sample consist of males drawn from 2000 to 2004 annual Microcensus. Earnings are deflated using the CPI and expressed in 2001 Euros."2nd gen." refers to second generation immigrants those who born in Germany or migrate younger than 6 years old and who have nationality other than German. Hours worked and income variable is only for men who report the employment payments as the main source of income and work at least 30 weeks per year and 30 hours per week. Adjusted income constructed by regressing log monthly income on nationality dummies, state dummies, age and age-squared interacted with nationality for the immigrants. "Hauptschule" is the lowest level high school in Germany. 
TABLE 5: Percentages of Working Male Immigrants by Country of Origin

\begin{tabular}{|c|c|c|c|c|c|c|}
\hline \multirow{4}{*}{$\underline{\text { Countries }}$} & \multicolumn{3}{|c|}{ 1989-91 census } & \multicolumn{3}{|c|}{ 2001-2004 census } \\
\hline & \multicolumn{3}{|c|}{ 1st gen. } & \multicolumn{3}{|c|}{ 2nd gen. } \\
\hline & Without & With & With age 5-18 & Age 20-45 & Age 20-33 & Age 25-33 \\
\hline & (1) & (2) & (3) & (4) & $(5)$ & $(6)$ \\
\hline France & 1.76 & 0.94 & 0.85 & 1.25 & 1.11 & 1.17 \\
\hline Greece & 5.37 & 7.8 & 6.81 & 8.2 & 7.34 & 8.66 \\
\hline Great Britain & 3.53 & 1.45 & 1.26 & 1.33 & 0.82 & 1.09 \\
\hline Italy & 14.53 & 14.34 & 13.59 & 17.28 & 16.47 & 17.27 \\
\hline Ex-Yugoslavia & 20.23 & 13.25 & 14.89 & 11.51 & 13.23 & 11.67 \\
\hline Italy & 2.1 & 1.02 & 0.77 & 2.71 & 1.45 & 1.57 \\
\hline Austria & 5.49 & 3.02 & 2.64 & 3.35 & 2.11 & 2.62 \\
\hline Poland & 2.59 & 1.66 & 1.48 & 0.9 & 0.63 & 0.56 \\
\hline Portugal & 1.69 & 2.07 & 1.8 & 1.97 & 1.9 & 2.01 \\
\hline Spain & 3.53 & 3.35 & 3.37 & 3.7 & 2.9 & 3.5 \\
\hline Turkey & 20.59 & 37.78 & 40.15 & 37.81 & 44.27 & 42.31 \\
\hline USA & 2.56 & 1.43 & 1.1 & 1.49 & 0.79 & 0.72 \\
\hline Remaining EU & 0.75 & 0.32 & 0.3 & 1.04 & 0.69 & 0.93 \\
\hline Other Europe & 2.34 & 1.9 & 1.99 & 3.03 & 2.53 & 2.38 \\
\hline Morocco & 0.58 & 0.61 & 0.71 & 0.8 & 0.95 & 0.89 \\
\hline Other Africa & 0.82 & 0.81 & 0.65 & 0.66 & 0.45 & 0.28 \\
\hline Iran & 0.65 & 0.57 & 0.45 & 0.48 & 0.4 & 0.36 \\
\hline Middle East & 0.36 & 0.43 & 0.39 & 0.42 & 0.4 & 0.32 \\
\hline Vietnam & 0.46 & 0.3 & 0.16 & 0.2 & 0.11 & 0.08 \\
\hline South East Asia & 0.82 & 0.78 & 0.67 & 0.3 & 0.21 & 0.12 \\
\hline Remaining world & 9.23 & 6.18 & 5.96 & 1.57 & 1.24 & 1.49 \\
\hline TOTAL & 4137 & 7427 & 5069 & 4978 & 3788 & 2484 \\
\hline $\begin{array}{l}\text { Notes:"1st gen" refers } \\
1991 \text { Microcensus "2 } \\
\text { Microcensus. Full tim } \\
\text { and work at least } 30 \\
\text { "Without" refers to fir } \\
\text { who have children bet } \\
\text { immigrants reported in }\end{array}$ & $\begin{array}{l}\text { generation } \\
\text { " refers to } \\
\text { ers are defii } \\
\text { per year an } \\
\text { ration immi } \\
\text { and } 18 \text { yea }\end{array}$ & $\begin{array}{l}\text { dll time } \\
\text { cond ge } \\
\mathrm{d} \text { as ind } \\
30 \text { hou }\end{array}$ & $\begin{array}{l}\text { orking male immig } \\
\text { ration full time wo } \\
\text { iduals who report th } \\
\text { per week. "With" } \\
\text { do not have child, } \\
\text { ng in their family i }\end{array}$ & $\begin{array}{l}\text { between } 25 \text { an } \\
\text { male immigra } \\
\text { employment pa } \\
\text { s to first gener } \\
\text { 'With age } 5-18 \text { ' } \\
89 \text { or } 1991 \text {. Th } \\
\text { d } 33,25 \text { and } 33 \text {. }\end{array}$ & $\begin{array}{l}\text { years old dra } \\
\text { drawn from } 20 \\
\text { nts as the main } \\
\text { immigrants } \\
\text { ers to first gen } \\
\text { ond generation }\end{array}$ & $\begin{array}{l}\text { n from } 1989 \text { al } \\
0 \text { to } 2004 \text { annu } \\
\text { source of incon } \\
\text { to have childre } \\
\text { ation immigran } \\
\text { full time workir }\end{array}$ \\
\hline
\end{tabular}


TABLE 6: Intergenerational Earning Elasticity Estimates

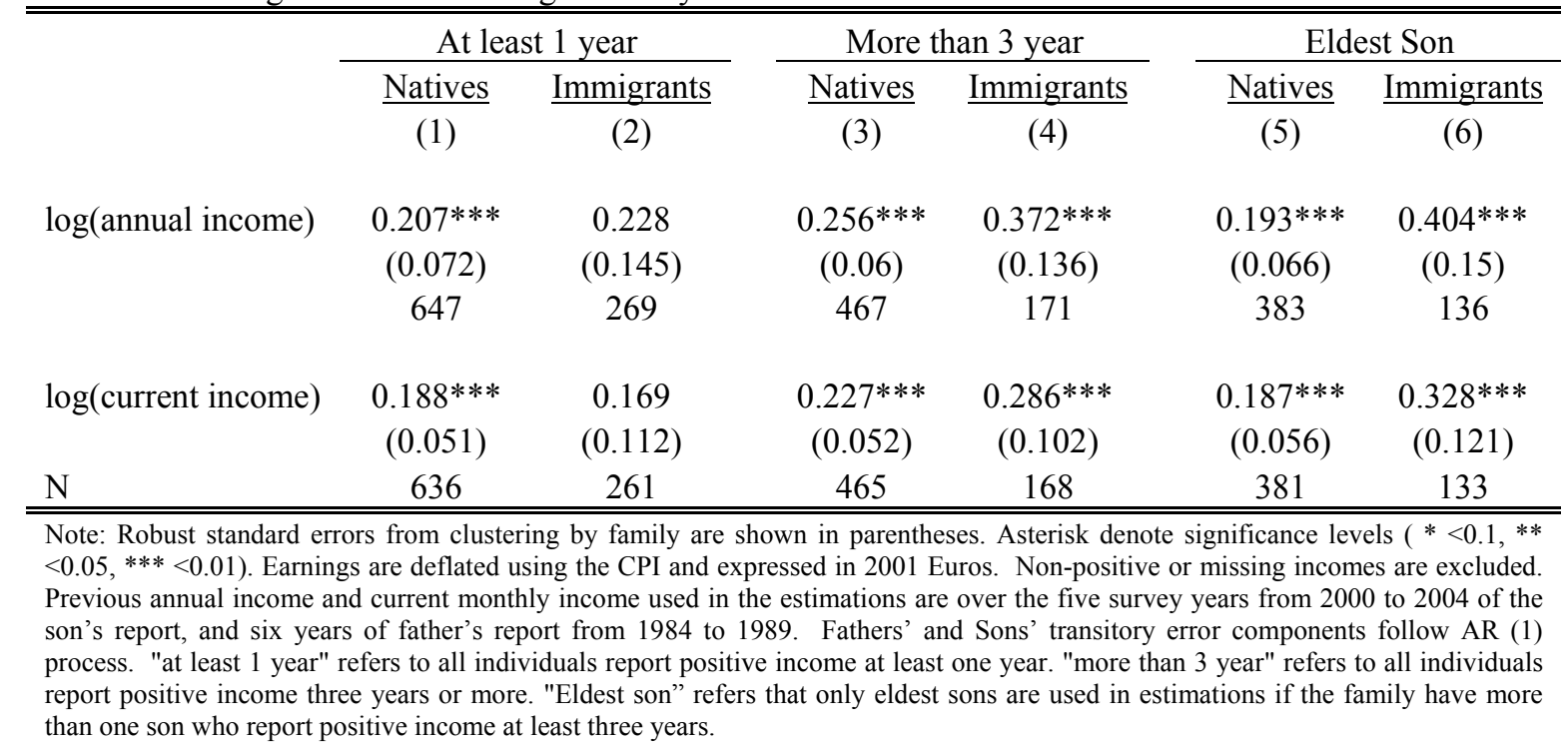


TABLE 7: Intergenerational Parental and Ethnic Capital Estimates using GSOEP

\begin{tabular}{|c|c|c|}
\hline$\underline{\text { Outcome }}$ & $\frac{\text { With Siblings }}{(1)}$ & $\frac{\text { Without Siblings }}{\underline{(2)}}$ \\
\hline \multicolumn{3}{|c|}{ log(annual income) } \\
\hline Parental Capital & $\begin{array}{l}0.352 \\
(0.03)^{* * *}\end{array}$ & $\begin{array}{l}0.387 \\
(0.047)^{* * *}\end{array}$ \\
\hline Ethnic Capital & $\begin{array}{l}0.819 \\
(0.11)^{* * *}\end{array}$ & $\begin{array}{l}0.617 \\
(0.122)^{* * *}\end{array}$ \\
\hline \multicolumn{3}{|l|}{ education } \\
\hline Parental Capital & $\begin{array}{l}0.31 \\
(0.02)^{* * *}\end{array}$ & $\begin{array}{c}0.29 \\
(0.037)\end{array}$ \\
\hline Ethnic Capital & $\begin{array}{l}0.26 \\
(0.48)\end{array}$ & $\begin{array}{l}0.219 \\
(0.511)\end{array}$ \\
\hline \multicolumn{3}{|l|}{ log(hourly wage) } \\
\hline Parental Capital & $\begin{array}{l}0.2 \\
(0.05)^{* * *}\end{array}$ & $\begin{array}{l}0.233 \\
(0.083)^{* *}\end{array}$ \\
\hline Ethnic Capital & $\begin{array}{l}1.05 \\
(0.32)^{* *} \\
\end{array}$ & $\begin{array}{l}0.86 \\
(0.339)^{* *} \\
\end{array}$ \\
\hline $\begin{array}{l}\text { Note: Robust standard e } \\
(*<0.1, * *<0.05, * * * \\
\text { missing incomes are exc } \\
\text { the son's report, and six } \\
\text { follow AR (1) process. } \\
\text { "Without brother" refers } \\
\text { years of schooling. "Eth } \\
\text { not only fathers in fathe }\end{array}$ & $\begin{array}{l}\text { Imily are shown in } \\
\text { ated using the CPI } \\
\text { the estimations are } \\
\text { om } 1984 \text { to } 1989 . \\
11 \text { sons who report o } \\
\text { port outcome at lea }\end{array}$ & $\begin{array}{l}\text { erisk denote significance } \\
2001 \text { Euros. Non-posit } \\
\text { vey years from } 2000 \text { to } 2 \\
\text { s' transitory error compc } \\
\text { hree years used in estima } \\
\text { ed in estimations. Educa } \\
\text { ionality measured by incl }\end{array}$ \\
\hline
\end{tabular}


Table 8: Least Square estimates of Earnings and Education Elasticity using Microcensus

\begin{tabular}{|c|c|c|c|c|}
\hline \multirow[t]{2}{*}{ Outcome } & \multicolumn{2}{|c|}{ Sample selection rules } & \multicolumn{2}{|c|}{ Results } \\
\hline & $\underline{\text { Fathers }}$ & $\underline{\text { Sons }}$ & $\underline{\text { Slope }}$ & $\underline{\mathrm{R} 2}$ \\
\hline \multicolumn{5}{|c|}{ log (monthly earning) } \\
\hline & with children & age $25-45$ & $\begin{array}{c}1.12 \\
(0.18)\end{array}$ & 0.68 \\
\hline & with children 5 to 18 years & age $20-33$ & $\begin{array}{c}0.86 \\
(0.20)\end{array}$ & 0.49 \\
\hline & with children 10 to 18 years & age $25-33$ & $\begin{array}{c}0.73 \\
(0.16)\end{array}$ & 0.54 \\
\hline \multicolumn{5}{|c|}{ years of son's education } \\
\hline & with children & age $25-45$ & $\begin{array}{c}0.42 \\
(0.06)\end{array}$ & 0.67 \\
\hline & with children 5 to 18 years & age $20-33$ & $\begin{array}{c}0.33 \\
(0.07)\end{array}$ & 0.49 \\
\hline & with children 10 to 18 years & age $25-33$ & $\begin{array}{c}0.39 \\
(0.07)\end{array}$ & 0.33 \\
\hline \multicolumn{5}{|c|}{$\begin{array}{l}\text { Notes: Fathers consist of males between } 25 \text { and } 65 \text { years old drawn from } 1989 \text { and } 1991 \text { Microcensus. Sons consist of males } \\
\text { drawn from } 2000 \text { to } 2004 \text { annual Microcensus. Earnings are deflated using the CPI and expressed in } 2001 \text { Euros. The monthly } \\
\text { earnings are constructed by regressing log monthly income of full time working natives, first and second generation immigrants } \\
\text { on nationality dummies, state dummies, age and age-squared interacted with nationality for the immigrants, then predicted } \\
\text { income is obtained by using the means of the demographic variables of each nation. The number of observation is } 20 \text {, } \\
\text { corresponding to the nationality of immigrants. Estimations are based on weighted least squares, with the number of sons from } \\
\text { each group as the weight. Robust standard errors from clustering by nationality are shown in parentheses. All estimates are } \\
\text { significant at } 1 \% \text { level. }\end{array}$} \\
\hline
\end{tabular}




\section{FIGURE 1:}

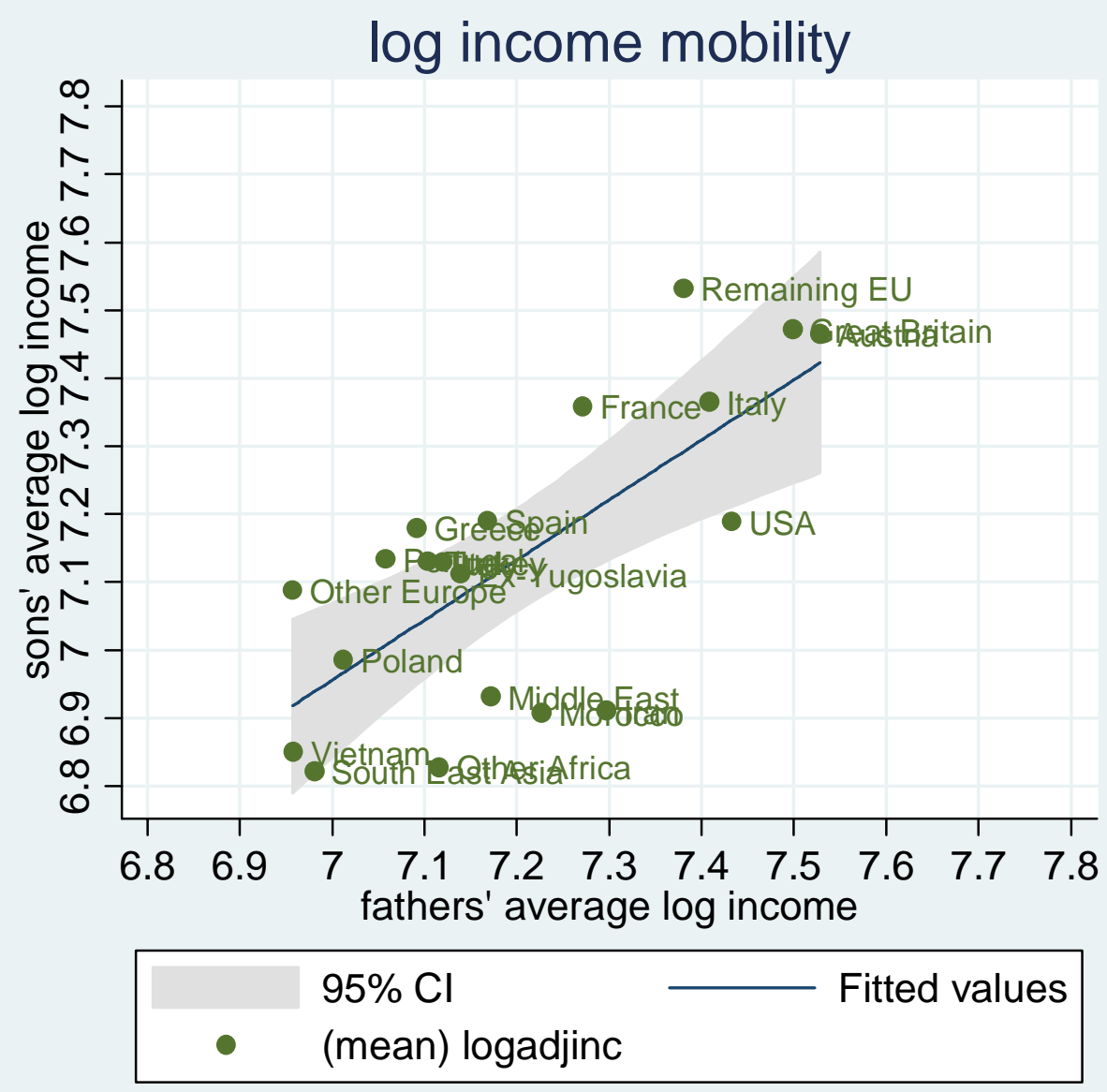




\section{FIGURE 2:}

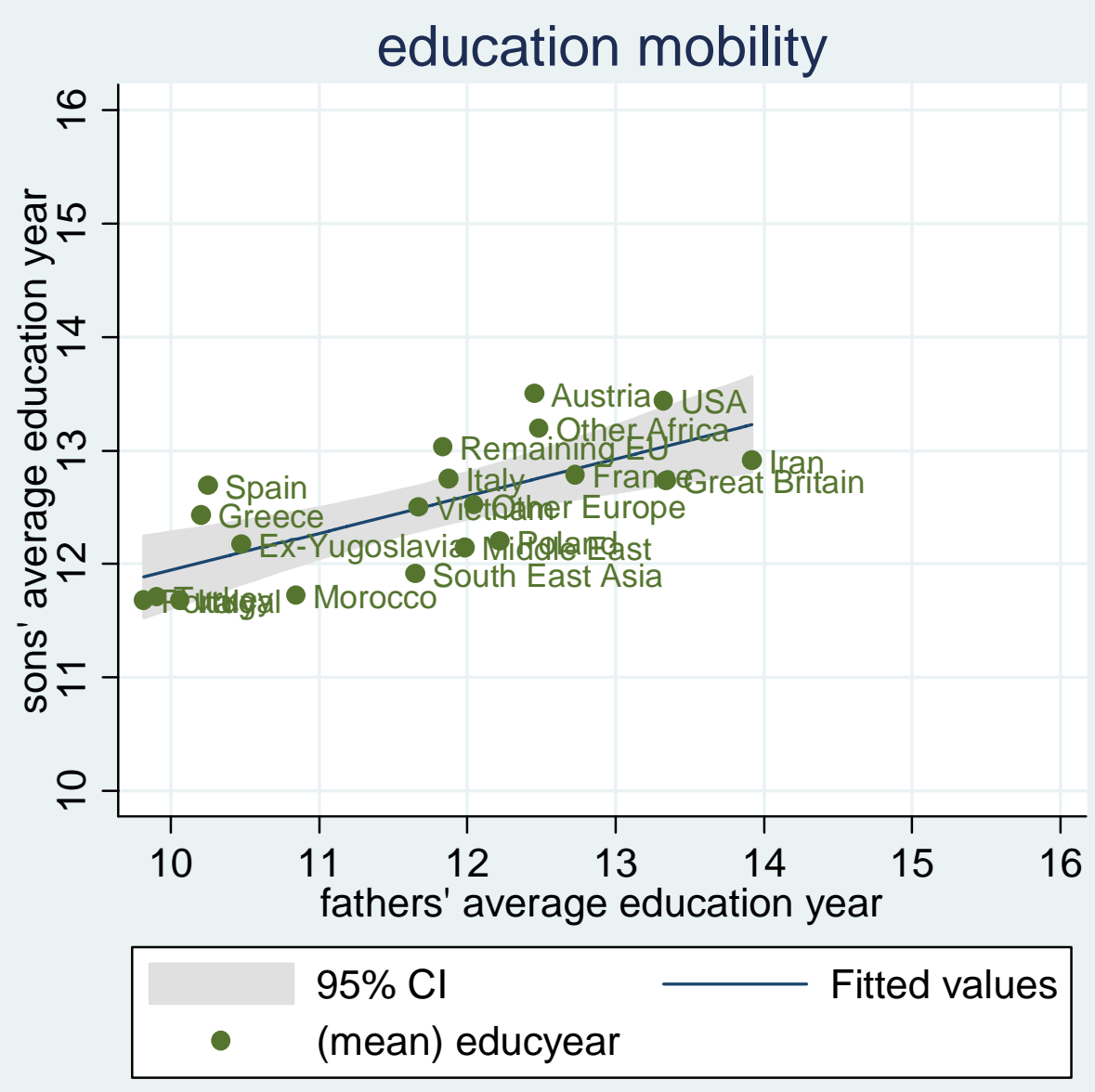


TABLE 9: Estimates of Earning Elasticity

\begin{tabular}{|c|c|c|c|c|c|}
\hline \multirow[t]{2}{*}{$\underline{\text { Authors }}$} & \multirow[t]{2}{*}{$\underline{\text { Countries }}$} & \multirow[t]{2}{*}{ Elasticity } & \multicolumn{2}{|c|}{ Average age or ranges } & \multirow[t]{2}{*}{$\underline{\text { Years }}$} \\
\hline & & & $\underline{\text { Sons }}$ & Fathers & \\
\hline Solon (1992) & U.S.A. & 0.39 & $25-33$ & 44 & 5 \\
\hline Zimmerman (1992) & U.S.A. & 0.42 & & 49.7 & 5 \\
\hline Couch Dunn (1997) & U.S.A. & 0.13 & 24.9 & 53 & 6 \\
\hline Björklund \& Jäntti (1997) & U.S.A. & 0.39 & $28-36$ & & 3 \\
\hline Mulligan (1997) & U.S.A. & 0.33 & $23-37$ & $40-45$ & \\
\hline Grawe (2004) & U.S.A. & 0.47 & $<46$ & 40.2 & 5 \\
\hline Mazumder (2001) & U.S.A. & 0.55 & $30-35$ & $27-69$ & 9 \\
\hline Grawe (2004) & Canada & 0.15 & & & 5 \\
\hline Corak (2001) & Canada & 0.26 & $32-35$ & & 5 \\
\hline Österbacka (2003) & Finland & 0.08 & 30.2 & 45.8 & 5 \\
\hline Couch Dunn (1997) & Germany & 0.11 & 22.8 & 51 & 6 \\
\hline Grawe (2004) & Germany & 0.09 & & 47.5 & 5 \\
\hline Lillard(2001) & Germany & 0.11 & 25 & 52 & $<14$ \\
\hline Bratberg,et al (2003) & Norway & 0.12 & $30-34$ & 48 & 3 \\
\hline Osterberg (2000) & Sweden & 0.13 & $25-51$ & 52 & 3 \\
\hline Dearden et al. (1997) & U.K. & 0.22 & 33 & 47.5 & \\
\hline
\end{tabular}


TABLE 10: Intergenerational Earning Elasticity Estimates

\begin{tabular}{|c|c|c|c|c|c|c|}
\hline \multirow[b]{2}{*}{$\underline{\text { Outcome }}$} & \multicolumn{2}{|c|}{ At least 1 year } & \multicolumn{2}{|c|}{ More than 3 year } & \multicolumn{2}{|c|}{ Eldest son } \\
\hline & $\frac{\text { Natives }}{(1)}$ & $\frac{\text { Immigrants }}{(2)}$ & $\frac{\text { Natives }}{(3)}$ & $\frac{\text { Immigrants }}{(4)}$ & $\frac{\text { Natives }}{(5)}$ & $\frac{\text { Immigrants }}{(6)}$ \\
\hline Years of Schooling & $\begin{array}{c}0.467 * * * \\
(0.049) \\
618\end{array}$ & $\begin{array}{c}0.303 * * * \\
(0.093) \\
252\end{array}$ & $\begin{array}{c}0.489 * * * \\
(0.058) \\
449\end{array}$ & $\begin{array}{c}0.335 * * * \\
(0.112) \\
165\end{array}$ & $\begin{array}{c}0.528 * * * \\
(0.058) \\
368\end{array}$ & $\begin{array}{c}0.324 * * * \\
(0.123) \\
132\end{array}$ \\
\hline Occupational Indices & $\begin{array}{c}0.170 * * * \\
(0.056) \\
285\end{array}$ & $\begin{array}{c}0.024 \\
(0.087) \\
196\end{array}$ & $\begin{array}{c}0.192 * * * \\
(0.06) \\
200\end{array}$ & $\begin{array}{c}0.038 \\
(0.09) \\
125\end{array}$ & $\begin{array}{c}0.218 * * * \\
(0.069) \\
162\end{array}$ & $\begin{array}{c}0.096 \\
(0.092) \\
97\end{array}$ \\
\hline Relative Gross Income & $\begin{array}{c}0.332 * * * \\
(0.084) \\
647\end{array}$ & $\begin{array}{c}0.414 * * * \\
(0.138) \\
269\end{array}$ & $\begin{array}{c}0.297 * * * \\
(0.064) \\
467\end{array}$ & $\begin{array}{c}0.521 * * * \\
(0.166) \\
171\end{array}$ & $\begin{array}{c}0.277 * * * \\
(0.068) \\
383\end{array}$ & $\begin{array}{c}0.499 * * * \\
(0.18) \\
136\end{array}$ \\
\hline Relative Net Income & $\begin{array}{c}0.275 * * * \\
(0.084) \\
647\end{array}$ & $\begin{array}{c}0.403 * * * \\
(0.143) \\
269\end{array}$ & $\begin{array}{c}0.312 * * * \\
(0.075) \\
467\end{array}$ & $\begin{array}{c}0.508 * * * \\
(0.172) \\
171\end{array}$ & $\begin{array}{c}0.272 * * * \\
(0.081) \\
383\end{array}$ & $\begin{array}{c}0.537 * * * \\
(0.199) \\
136\end{array}$ \\
\hline Annual Labor Income & $\begin{array}{c}0.177 * * \\
(0.069) \\
647\end{array}$ & $\begin{array}{c}0.344^{*} \\
(0.192) \\
269\end{array}$ & $\begin{array}{c}0.255^{* * *} \\
(0.059) \\
467\end{array}$ & $\begin{array}{c}0.368^{*} \\
(0.193) \\
171\end{array}$ & $\begin{array}{c}0.225^{* * *} \\
(0.063) \\
383 \\
\end{array}$ & $\begin{array}{c}0.410^{*} \\
(0.217) \\
136 \\
\end{array}$ \\
\hline
\end{tabular}

